"Determinants of bank profitability for the selected private commercial banks in Bangladesh: a panel data analysis"

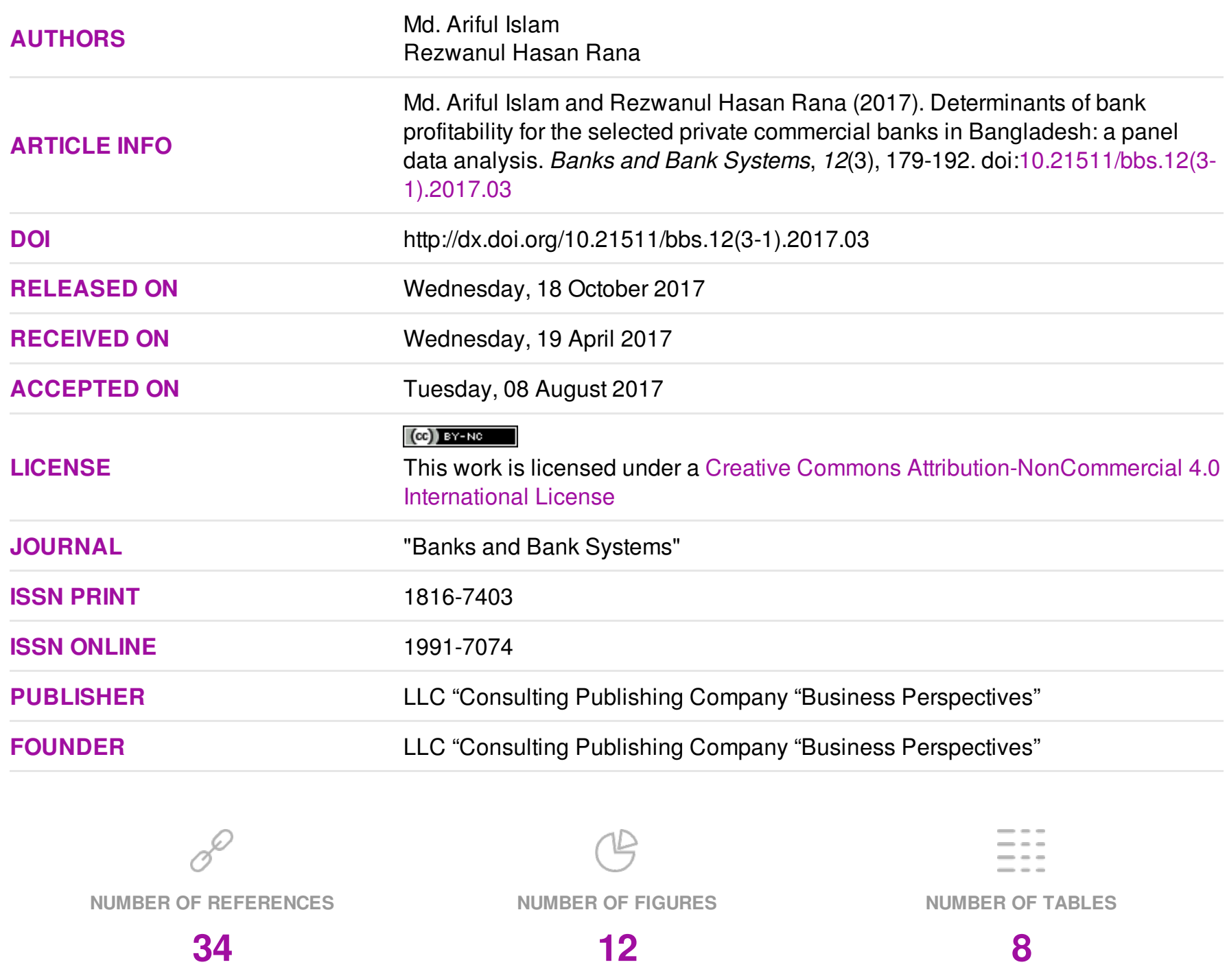

(C) The author(s) 2023. This publication is an open access article. 


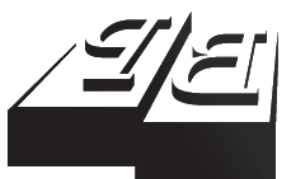

BUSINESS PERSPECTIVES

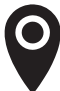

LLC “CPC "Business Perspectives" Hryhorii Skovoroda lane, 10, Sumy, 40022, Ukraine

www.businessperspectives.org

Received on: $19^{\text {th }}$ of April, 2017 Accepted on: $8^{\text {th }}$ of August, 2017

(C) Md. Ariful Islam, Rezwanul Hasan Rana, 2017

Md. Ariful Islam, DBA Candidate, University of Dhaka, Banker of Mutual Trust Bank Ltd, Bangladesh.

Rezwanul Hasan Rana, Ph.D. Candidate, University of Southern Queensland, Australia

\title{
DETERMINANTS OF BANK PROFITABILITY FOR THE SELECTED PRIVATE COMMERCIAL BANKS IN BANGLADESH: A PANEL DATA ANALYSIS
}

\begin{abstract}
This study aims to investigate the determinants of profitability of fifteen selected private commercial banks in Bangladesh over the period 2005-2015. The study emphasizes on the internal factors that affect bank profitability. This research uses panel data to explore the impact of the nonperforming loan, cost to income ratio, loan to deposit ratio, commission fees, cost of fund and operating expenses on the profitability indicators of banks like return on asset and return on equity. The experimental outcomes have found strong evidence that nonperforming loan (NPL) and operating expenses have a significant effect on the profitability. Moreover, the results have shown that higher NPL may lead to less profit due to the provision of classified loans. Again, higher loan to deposit (LD) ratio and cost of fund contribute towards profitability, but their impacts are not significant in the private commercial banks of Bangladesh.
\end{abstract}

\section{Keywords}

JEL Classification bank, NPL, ROA, ROE, profitability, Bangladesh, operating expenses, panel data.

\section{INTRODUCTION}

The bank is a financial institution authorized to get deposits and make loans. A strong banking sector can deal with negative shocks and contribute to the stability of the financial system. The profitability of financial institutions like the bank is affected by numerous factors (Ani et al., 2012). Determinants of bank profitability can be divided into internal and external factors. Internal determinants of bank profitability can be characterized by variables that impact bank's administrative choices and policy objectives (Staikouras \& Wood, 2011). These variables incorporate internal components to each financial institution and a few essential external forces. The fundamental conclusion rising up out of previous studies is that internal factors clarify an extensive proportion of banks' productivity. Operational efficiency is the major point in deciding performance of the banks (Oral \& Yolalan, 1990). The internal components are controllable variables which are cost efficiency, liquidity, asset quality, and capital adequacy. Previous studies used some internal variables to measure profitability (Almazari, 2014). We used the latest data of past ten years about private commercial banks of Bangladesh thus the result of this study depicts the current scenario of bank profitability in Bangladesh. 
Measures of after-expense rate of return, like the return on average total assets (ROA) and the return on total equity (ROE), are broadly used for assessing the performance of the banks. Banks have strong significance in terms of the strength of a financial system and assurance of its sound financial structure of a country. Among the controllers in money related framework of a country, banks have capacities to finance, utilize assets and render administrative services. However, the profit-making objective of the banks separates them from other money-related organizations.

Unlike some previous studies which measured the factors of bank profitability (Duraj \& Moci, 2015), we have used both ROA \& ROE as dependent variables in the model. Major emphasis has been given to determining the impact of non-performing loans (NPL). This study may add new conclusion to the finance literature on the profitability of banking systems.

In this research, two crucial questions will be asked to find out the determinants of banks' profitability. They are:

1. what determines the bank profitability of the selected private commercial banks in Bangladesh?

2. how NPL affects the profitability of private commercial banks in Bangladesh?

So the main objectives of the study are:

- to determine the profitability of private commercial banks in Bangladesh;

- to understand the effect of NPL on banks' profitability in Bangladesh.

\section{LITERATURE REVIEW}

This section presents the overview of previous studies related to the determinants of banks' profitability in Bangladesh. Earlier studies were country specific and others considered panel of countries for reviewing the determinants of bank profitability (Ani et al., 2012). These studies used return on assets (ROA) and return on equity (ROE) as the dependent variables. The internal factors NPL, cost to income ratio, LD ratio, cost of fund, commission and operating expenses were considered as control variables.

Sufian (2011) studied the profitability of banks in Korea. He found that Korean banks with lower liquidity levels tend to show higher profitability. Again, Dietrich et al. (2011) studied the profitability of Swiss banks and concluded that equity to total assets ratio, cost to income ratio, deposit growth rate, funding cost, interest income, effective tax rate and ownership structure negatively affect banking profitability in Switzerland.

Likewise, Smith et al. (2003) studied profitability of the European banks, and their results showed that among bank-specific determinants loan to assets ratio, the loan loss provisions have inverse effect, but the level of equity and funding gap positively affect banks' profit. Similarly, Athanasoglu et al. (2006) studied the banking profitability determinants of Greek banking. The results indicate that equity level, productivity, inflation and cyclical output have significant positive relationship, while loan loss provision and operating expenses have the significantly negative relationship with banks' profitability.

Furthermore, Pasiouras et al. (2007) in a study of fifteen EU countries found a significant positive relationship between banking profit, equity level, liquidity position, concentration, inflation and GDP growth rate. They also concluded that cost of fund and size variables negatively impact banking profitability. Chantapong (2005) studied the performance of domestic and foreign banks in Thailand during the period 1995-2000. He found that financial restructuring program improved the profitability of both foreign and domestic banks. In another study, Sufian and Habibullah (2009) studied the profitability of the Chinese banking sector during the period 2000-2005. They have found that liquidity, credit risk, and capitalization are the top three determinants that have the positive impact on the state-owned commercial banks' profitability.

It is noticeable that previous studies have either used ROA or ROE as the predictor variable to determine the bank's profitability. But in this study, 
we have used both ROA and ROE to assess the profitability of selected private commercial banks of Bangladesh. Return on assets (ROA) reflects the ability of a company to generate profits from its assets and it's very important for bank's management to know about the bank's ROA. ROA is primarily an indicator of managerial efficiency, as well as it indicates the return to shareholders on their equity.

For example, Gottard et al. (2004) employed return on equity (ROE) as a measure of profitability. In many European banks, the off-balance-sheet business makes a major contribution to total profit. The earnings generated from these activities are excluded from the denominator of ROA. ROE has been used as the key ratio for the evaluation of bank profitability. In another study, Swamy (2012) used panel data techniques to study the determinants of bank asset quality and profitability. He used robust datasets for the period 1997-2009. The findings of the study revealed some interesting inferences opposing the established opinions. Priority sector credit was found insignificant to affect the nonperforming assets, contrary to the general perception.

According to the Global Financial Stability Report of International Monetary Fund (2009), to improve profitability, banks should focus on managing their asset quality along with determinants of profitability. The increasing incidence of poor bank asset quality requires attention at the elements that affect the performance of a bank's profitability and asset management. Similar to the previous conclusions, Demirguc-Kunt (1989) and Barr and Siems (1994) have also stated that asset quality is a major predictor of insolvency. Therefore, high level of nonperforming loans has been found as a major cause of failures of the banking institutions. Additionally, the problem of nonperforming assets (NPAs) has become identical to functional effectiveness of financial intermediaries and the major cause of the economic problems.

Barseghyan (2004) identified the relationship between the Japanese government's unwillingness to solve the bad loan problem and the economic slowdown. He concluded that the government's reluctant behavior deteriorated the economic situation in Japan. Again, Lis et al.
(2001) used an equation model to explain the bank loan losses in Spain using some major indicators like GDP growth rate, debt-equity ratio, regulations, loan growth, bank branch growth rates, size of the bank (assets over total size), collateral loans, net interest margin, capital-asset ratio and market power of the default companies in the market.

Ranjan and Dhal (2003) analyzed the NPAs of public sector banks in India in terms of credit, bank size and macroeconomic condition. In this empirical analysis, they have shown that terms of credit have a significant influence on the banks' NPAs in the presence of bank size and macroeconomic shocks. However, Bhattacharya (2001) has pointed that increasing interest rate push the quality borrowers over to other opportunities such as capital markets, internal accruals for their necessity of funds.

Additionally, Carter et al. (2004) and Carter and McNulty (2005) suggested that monitoring may be an influential factor to contribute small bank's financial performance because risk-adjusted loan's yield and spread are greater for small banks. According to their research, the most important reason for the positive relationship between monitoring and performance is the ability of the small banks to discover economically valuable information. It helped to have an idea about a firm's financial condition by monitoring the firm's demand deposit account. Again, Kaya (2002) examined the determinants of productivity for Turkish banks for the 1997-2000. He found that that capital, liquidity, personal expenditures, advances, nonperforming loans, and deposits are the determinants of bank profitability.

The above discussions validate a strong linkage between bank's profitability and internal factors like; NPL and operating expenses. According to the nature and use of each study mentioned in the literature review, a number of explanatory variables have been proposed in this study as determinants of private commercial bank's profitability in Bangladesh. We have taken nonperforming loans (NPLs), cost to income ratio, cost of fund, loan-deposit ratio, commission and operating expenses to find the relationship with return on assets (ROA) and return on equity (ROE). 


\section{BANKING PERFORMANCE INDICATORS}

The private commercial banks have been playing a vital role in achieving the economic growth of Bangladesh in the past few years. All the banks in Bangladesh are divided in to private commercial banks (PCBs), state-owned commercial banks (SCBs), development financing institutions (DFIs) and foreign commercial banks (FCBs). In this section, we provide a brief discussion of the existing state of banking sector in Bangladesh. All the graphs are authors' own calculations, generated from the data of Bangladesh banks annual reports from 2005 to 2015.

NPL to total loans has a downward trend for most of the banks like SCB, PCB, whereas it's the upward trend in case of DFI and FCB. For PCB, NPL has a decline of $42.86 \%$ in the year 2014 compared to 2007. However, for DFI and FCB have growth of $34.21 \%$ and $52.63 \%$, respectively.
There is an increase in the amount of NPL for PCB over the period of time and in 2014, the number goes at BDT 184.3 billion, which can refer to the poor managerial capacity to manage the loans properly. There might be so many reasons behind these classified loans which work for all other above mentioned types of banks.

The above graph shows the amount of the NPLs for all the banks from the year 2007 to 2014 along with provision required for the NPLs, excess or shortfall and the provision maintained by the banks. There is an increasing trend of NPLs amount and required provision over the period of times. But the maintained provision didn't show the mirror picture accordingly and there is increased movement of provision maintained ration from 2007 to 2008 and 2009, whereas the ratio has fallen from $103.04 \%$ to $78.3 \%$ in the year 2011 and $97.20 \%$ in 2014 from 99\% (2013).

\section{Ratio of net NPL to total loans by type of banks}

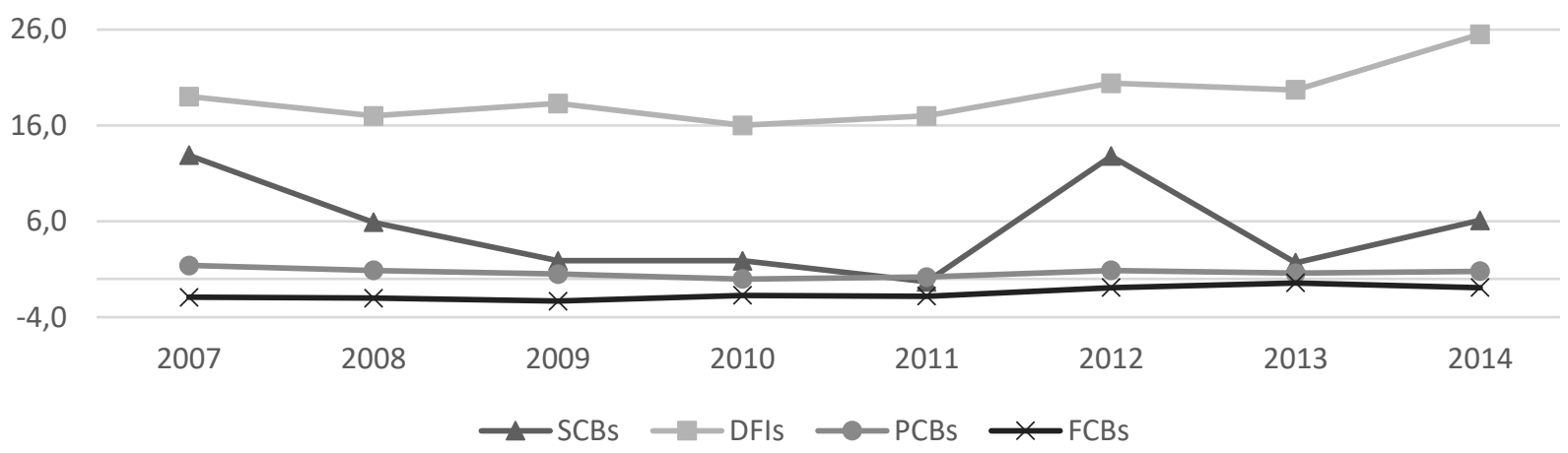

Figure 1. Ratio of net NPL to total loans by type of banks

\section{Amount of NPLs}

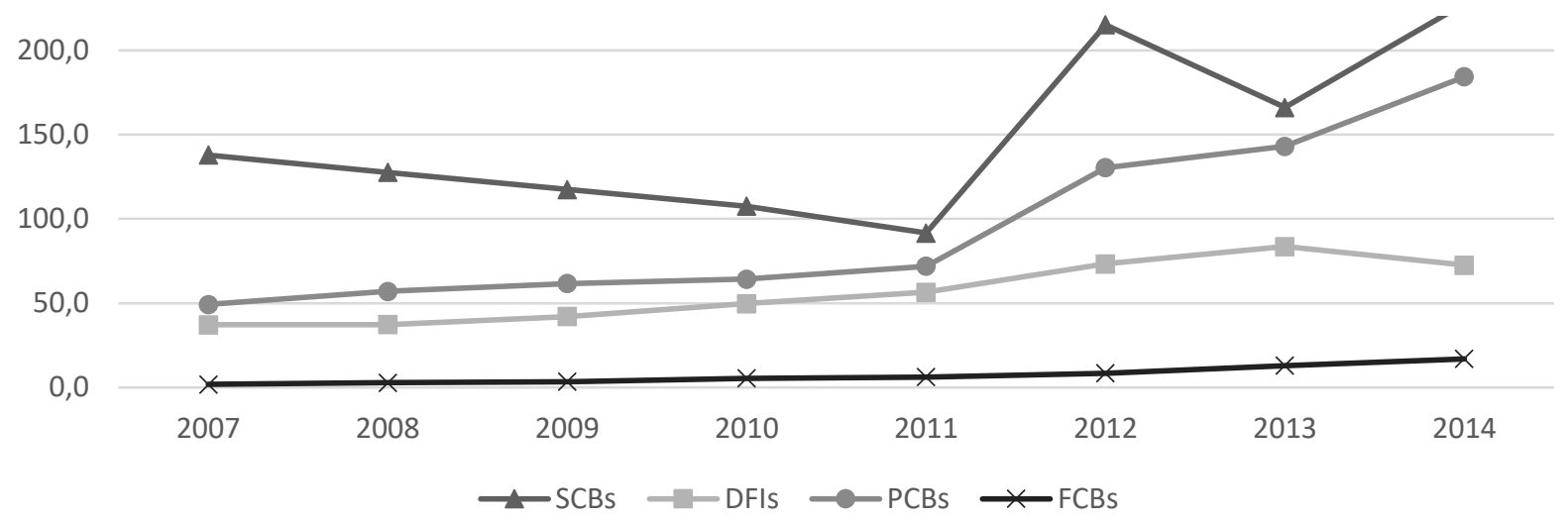

Figure 2. Amount of NPL to total loans by type of banks 


\section{Required provision and provision maintained all banks}

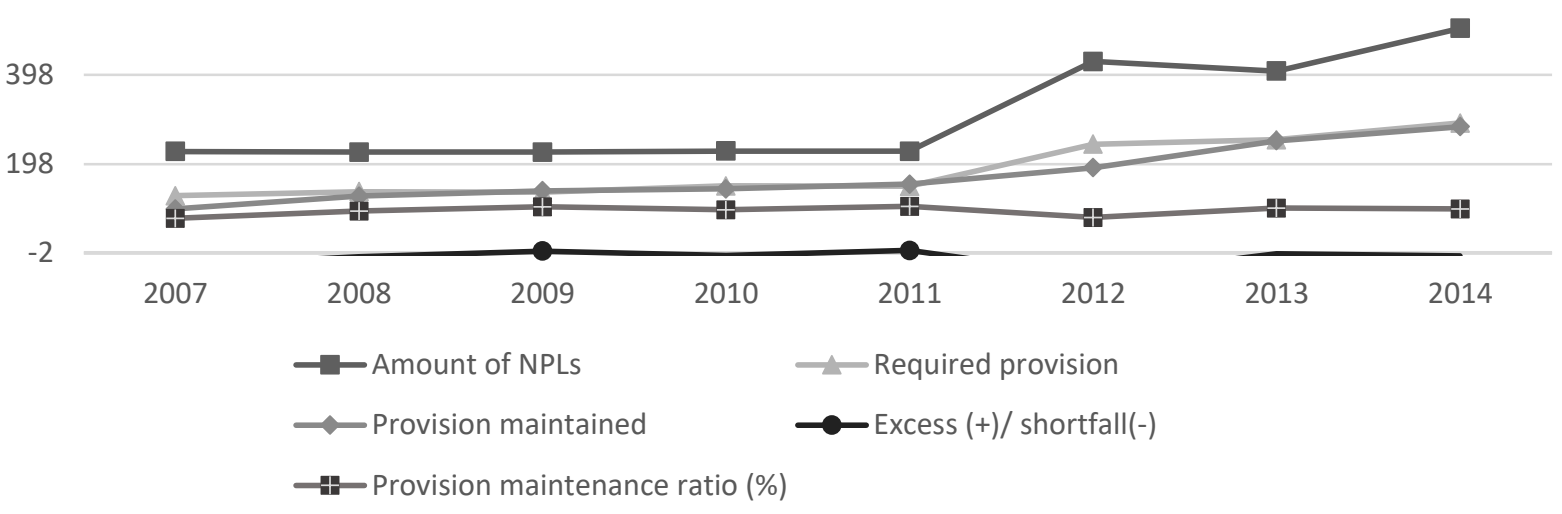

Figure 3. Required provision and provision maintained by all banks

\section{Comparative position of provision adequacy}

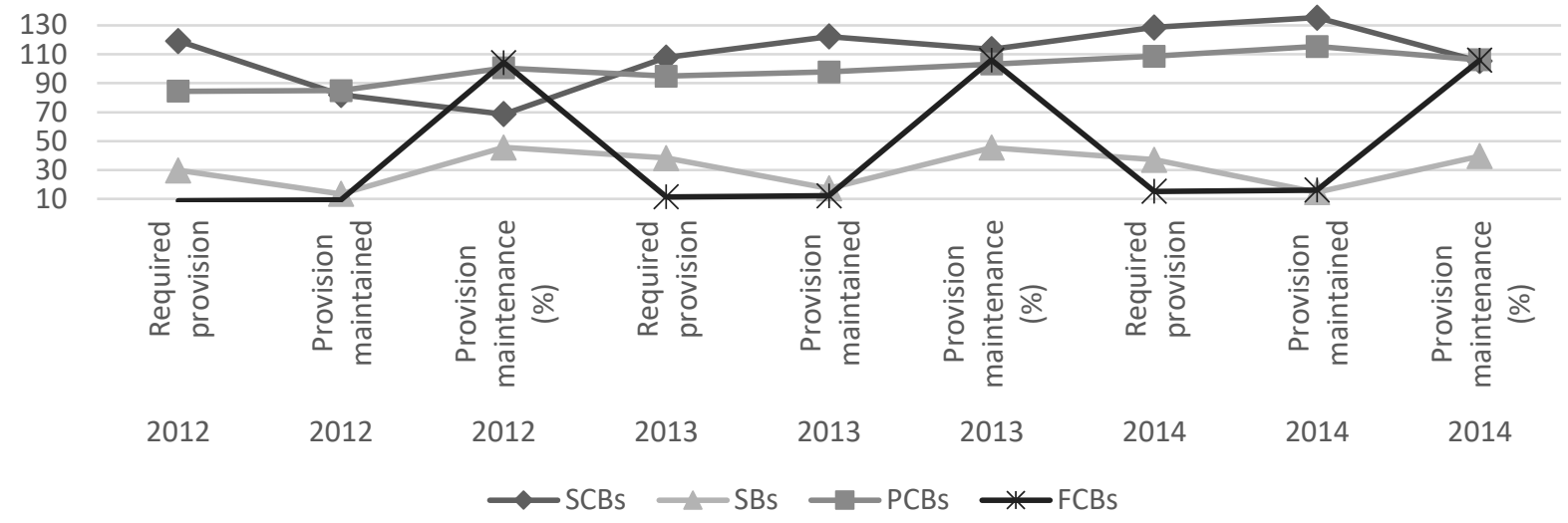

Figure 4. Comparative position of provision adequacy all banks

PCB has maintained the provision required to maintain over the three consecutive years (2012-2014), which has not maintained by the peer type of banks in such a managed way.

Private commercial banks play a great role in the banking industry and we can see this in the graph since in every category the number exceeds all peer type of banks. There are 39 banks which consist of 3,982 branches. Total assets and deposits are more than any other type of banks in the country.

RWA is one of the most important things to be considered by the banks to maintain MCR (minimum capital requirement) and this has an upward trend over the period of time for all bank types, since they are having more assets which are quite risky. For PCBs, it's $10 \%$ to $13 \%$ from 2007 to 2014.
NPL ratio is lower than any other type of banks for each and every year from 2011 to 2014 and in the year 2007-2010 it has a little higher percentage of ratios. The NPL ratio is the highest for SCBs.

Again, it is also imperative to compare the current financial position of the fifteen commercial banks whose data has been used to conduct this study. These graphical presentations are authors own calculation using the data collected from all the fifteen banks. The comparison shows only those variables which we have found significant in our study. The data of the graphs includes the period from 2005 to 2015.

The variable cost of fund shows volatility for all the banks during 2010, but interestingly for most of the banks, the cost of deposit went up slightly in 2015 compared to 2005 . On the other hand, the operating expenses depict a rising trend for all fif- 
Structure of banking system 2015 (June)

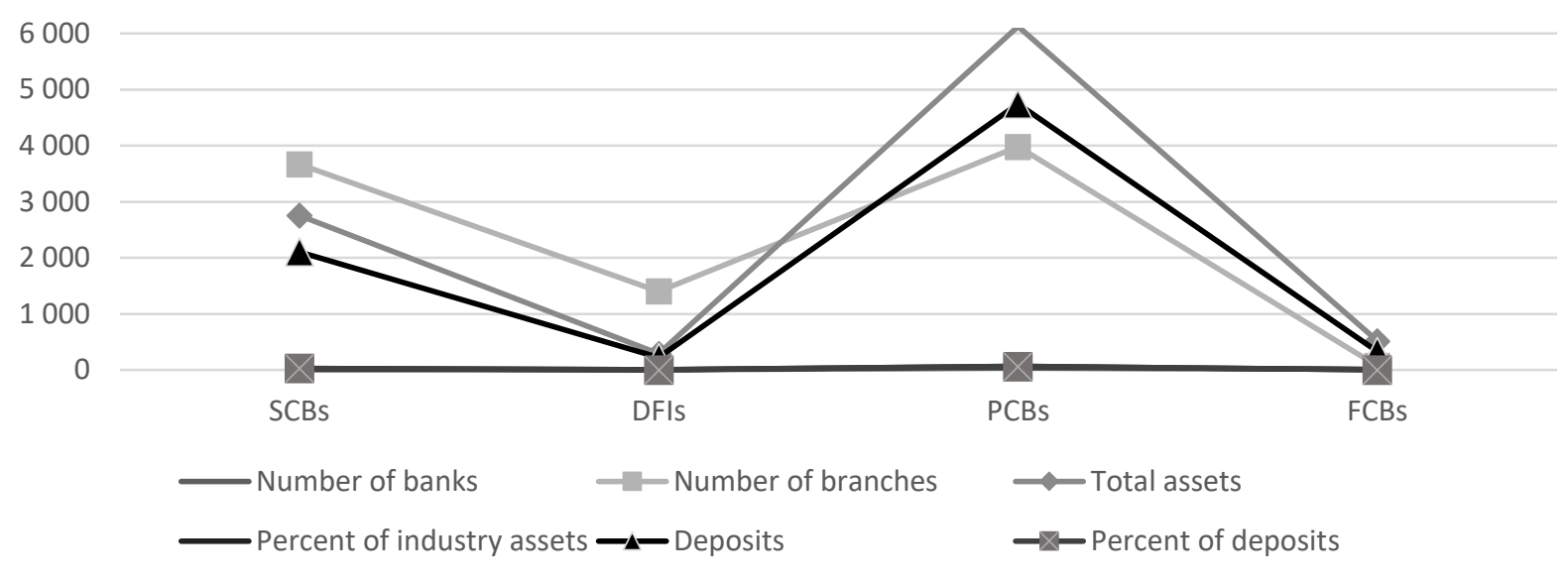

Figure 5. Comparative position of the structure of the banking system Capital to risk weighted assets ratio by type of banks

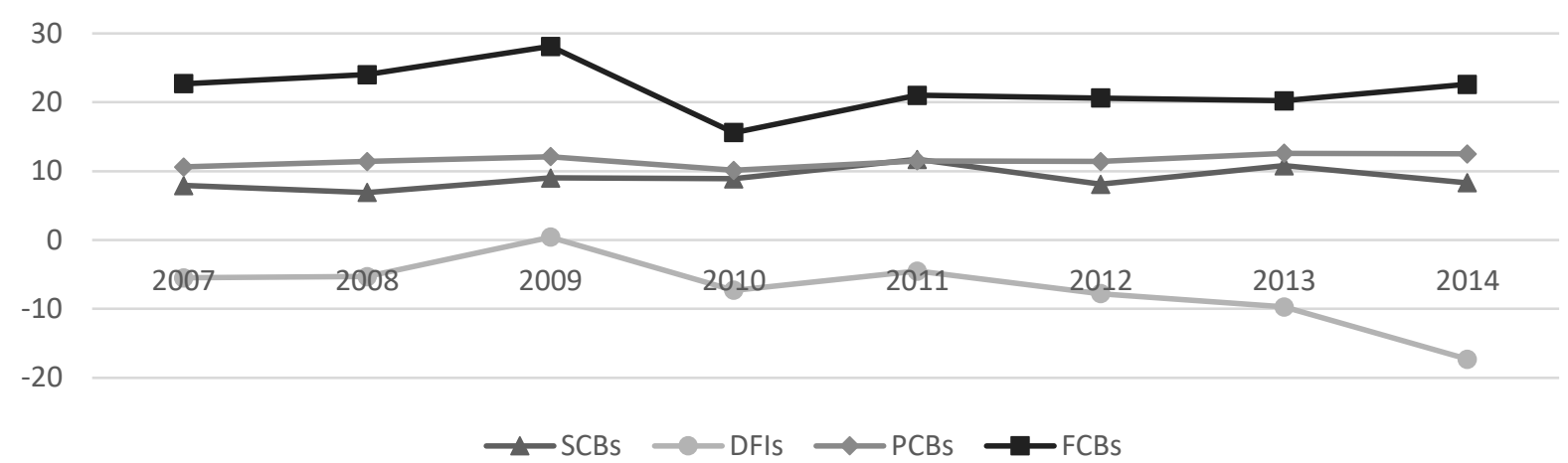

Figure 6. Comparative position of capital to risk weighted assets ratio by type of banks NPL ratios by type of banks

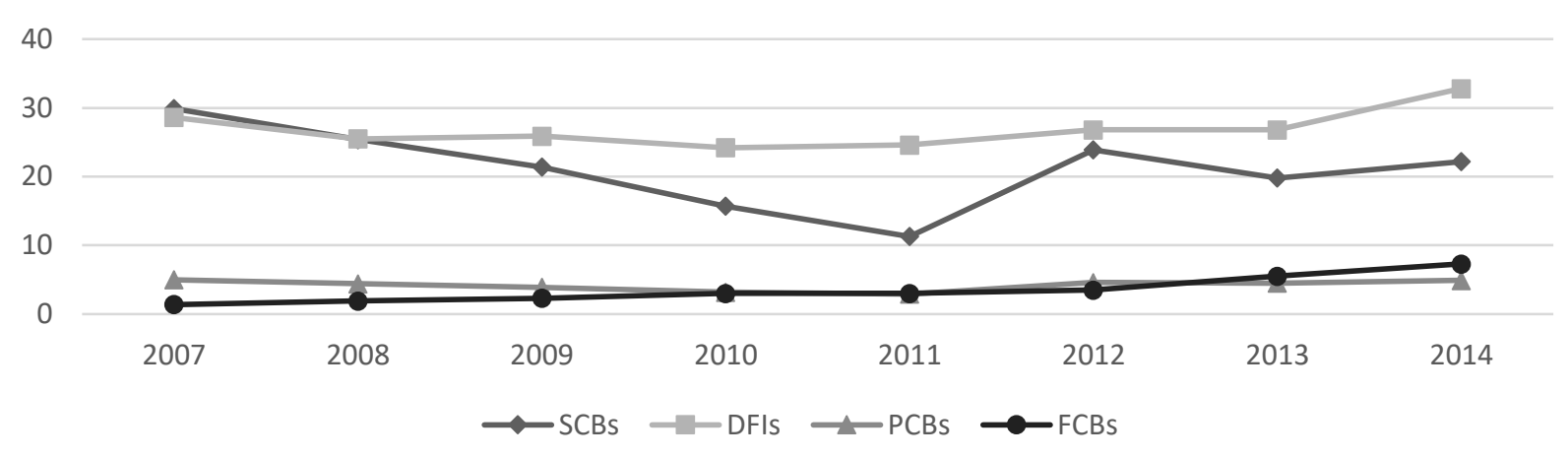

Figure 7. Comparative position of NPL ratios by type of banks

teen banks so as commission earned. It means banks are spending more money now than before for their day to day activities. This can severely affect the profitability of the banks. Last but not least, the level of non-performing loans presents a mix picture among the banks. Pubali Bank Ltd and AB Bank Ltd has significantly reduced the level of non-performing loan, but the non-performing loan for Prime Bank Ltd has gone up at an alarming rate in recent years. 


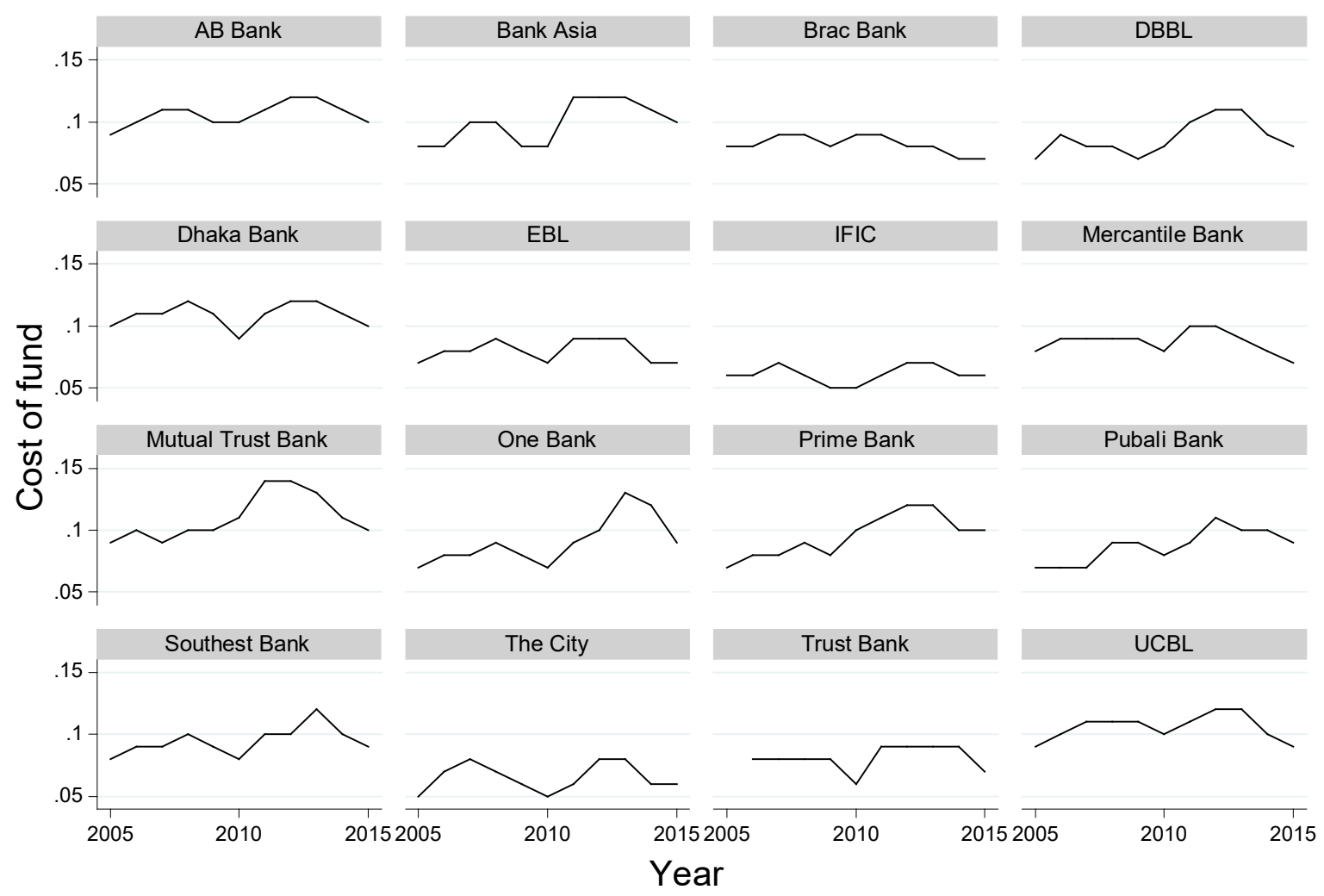

Graphs by bank name

Figure 8. Comparison of the cost of fund from the period 2005 to 2015

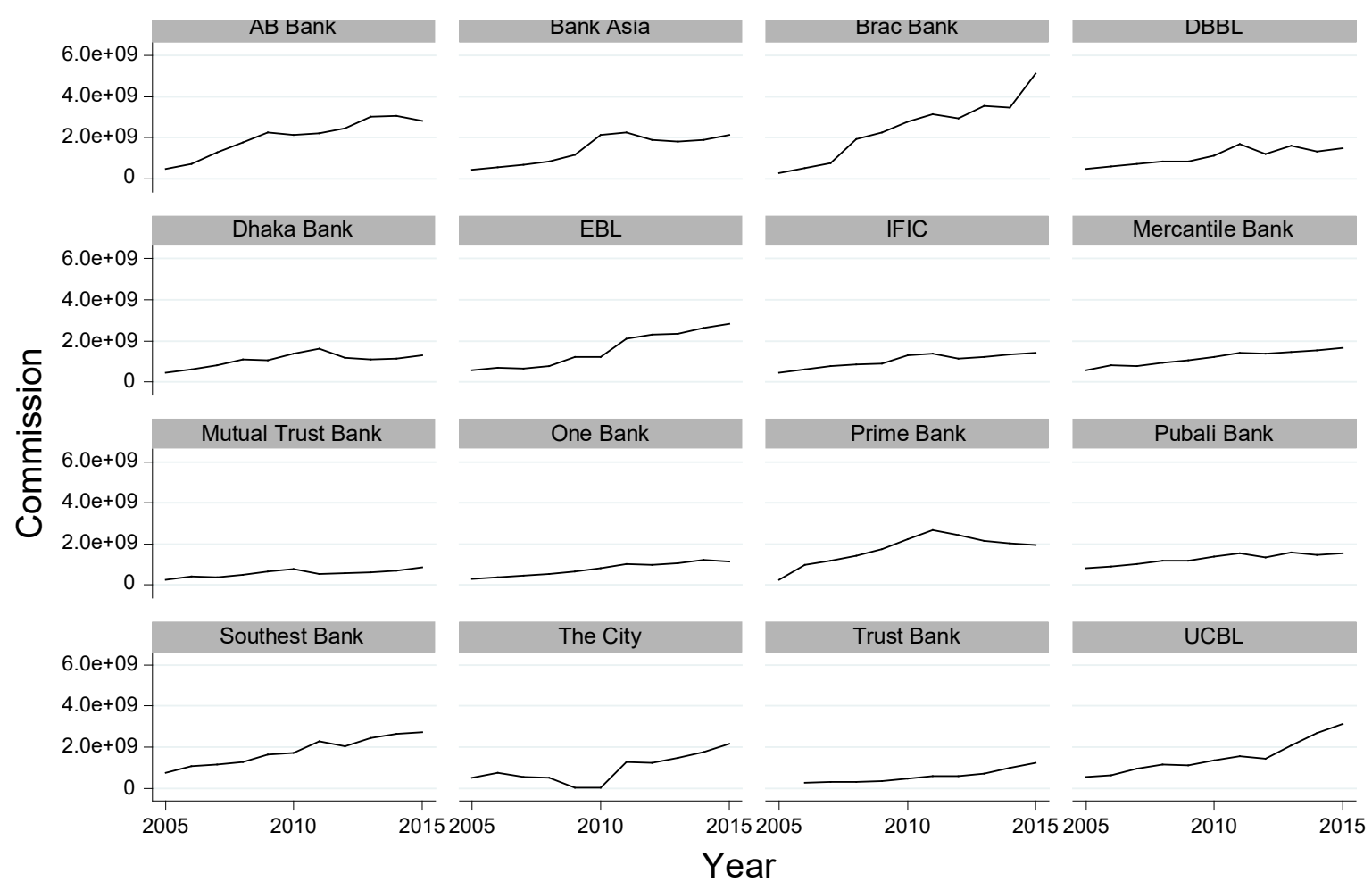

Graphs by bank name

Figure 9. Comparison of the commission earned from the period 2005 to 2015 


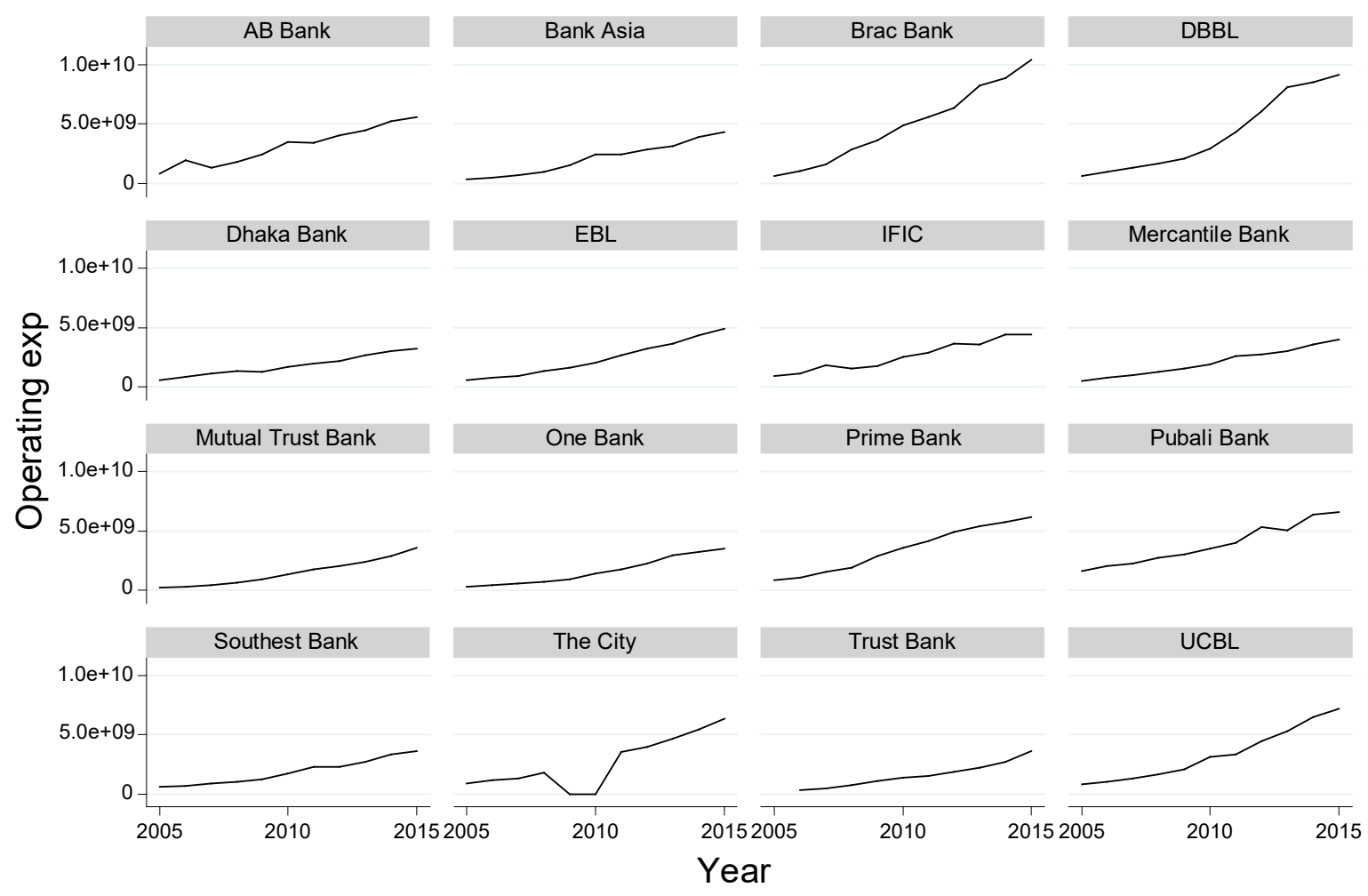

Graphs by bank name

Figure 10. Comparison of the operating expenses from the period 2005 to 2015
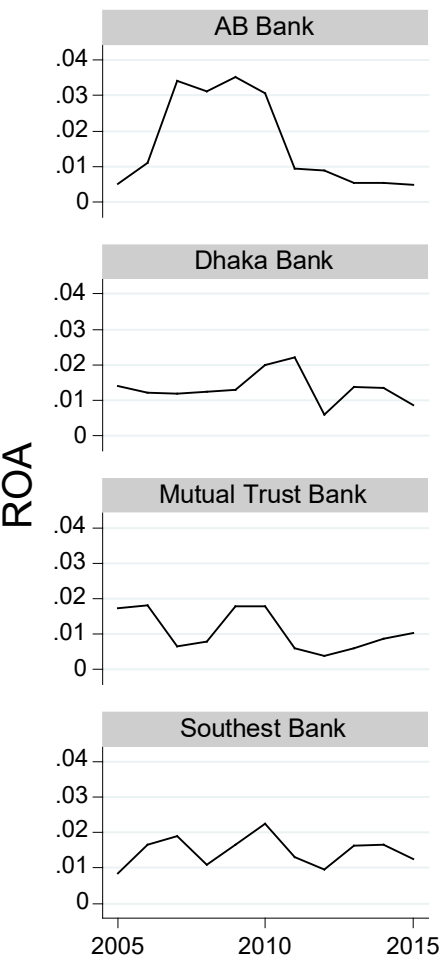

Graphs by bank name
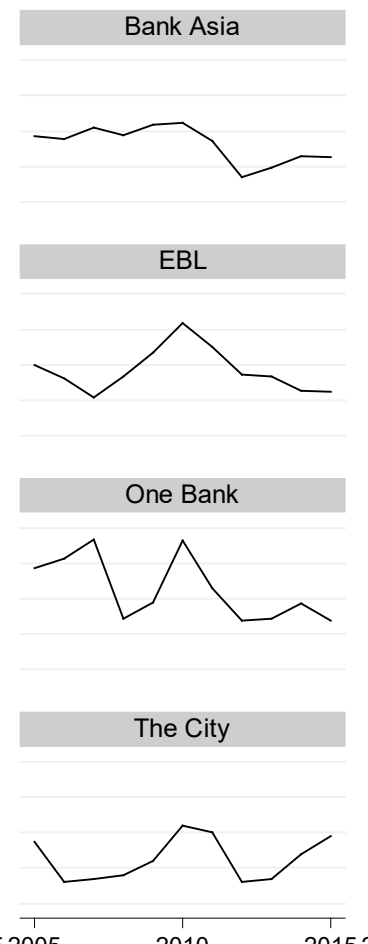

Year

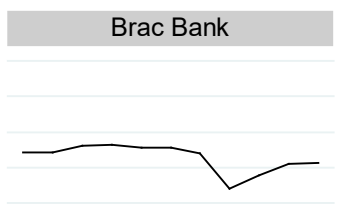

IFIC

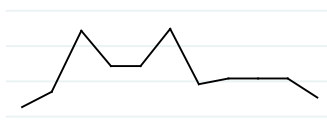

Prime Bank

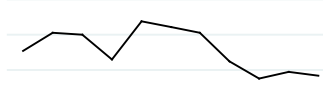

Trust Bank

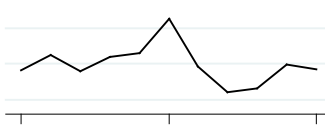

DBBL

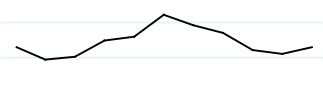

Mercantile Bank

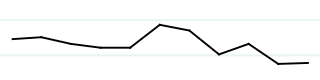

Pubali Bank

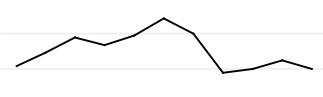

UCBL

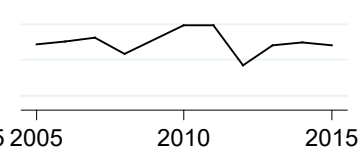

Figure 11. Comparison of the return on asset from the period 2005 to 2015 


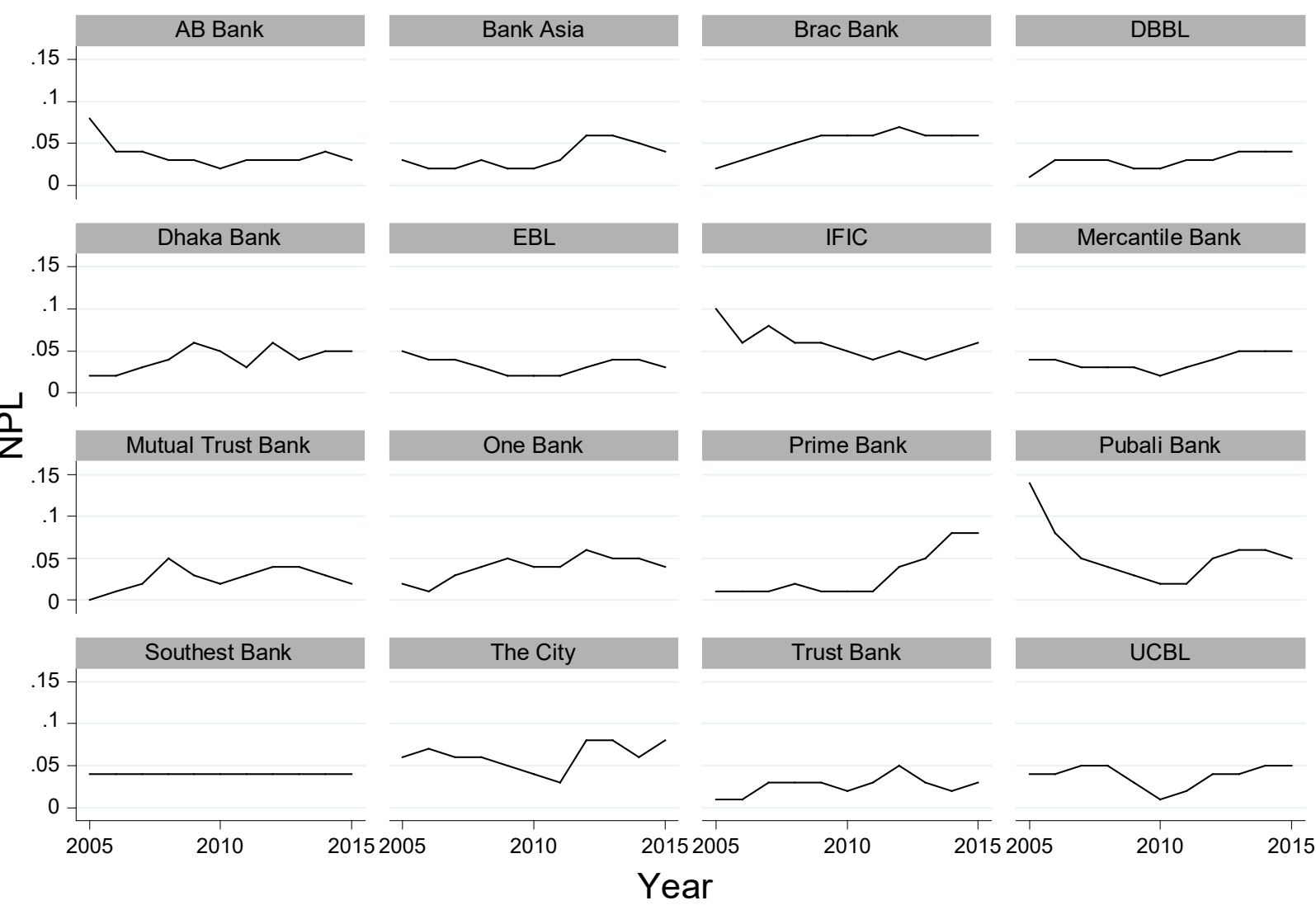

Graphs by bank name

Figure 12. Comparison of the nonperforming loans from the period 2005 to 2015

\section{DATA DESCRIPTION}

The study is based only on secondary data. For this research, we have used the data published in annual reports of selected PCBs of Bangladesh for the years 2005-2015 and Bangladesh Bank.

\subsection{NPL}

Nonperforming loan (NPL) is a loan on which borrower does not make any interest and principal payments for at least 90 days (Bangladesh Bank, 2016). Banks generally set back up money to cover potential losses on loans (loan loss provisions) and write off bad debt in their profit and loss account. In some countries, banks can sell NPLs at a discount - to specially established asset management companies (AMCs), which attempt to recover at least some of the money repaid (Scardovi, 2015).

\subsection{Cost to income ratio}

Cost to income ratio is one of the key financial measures, particularly important in measurement of productivity, efficiency and valuing in company. It shows the cost of the company in relation to its income. To get the ratio, divide the operating costs by operating income. It gives investors a clear view of how efficiently the firm is being run. It is also known as efficiency ratio. It covers both operating expenses and all types of provision (Vittas, 1991).

\subsection{Loan deposit ratio}

The loan to deposit ratio is the commonly used statistic for assessing bank's liquidity by dividing the bank's total loans by its total deposits. High ratio refers to the bank's inadequate liquidity to cover 
any unforeseen fund requirements. Conversely, if the ratio is too low, may be indicate that inadequate lending opportunities or reluctance to accept the available lending risks. So the bank may not be earning as much as it could be (McNaughton \& Barltrop, 1992).

\subsection{Cost of fund}

Cost of fund is the rate of interest that depositor will receive from the bank in order to keep their money in the bank. So cost of fund is the interest cost paid by a financial institution for the use of money from different sources. The spread between the cost of funds and interest rate charged to borrowers are the main part of profit of banks. It is weighted average interest rate of the interest bearing liabilities of a financial institution (Bangladesh Bank).

\subsection{Operating expenses}

Operating expenses is such kind of expenses of a company that incurred in carrying out an organization's day-to-day activities, but not directly associated with investing decisions. So, operating expenses of bank are non-interest expenses connecting to the regular business of the bank (McNaughton \& Barltrop, 1992).

\subsection{Commission and fee income}

The fees and commission charged to customers (borrower and depositor) for avail banking services from bank. Charges that generate commission and fee income are non-funded business commission, overdraft charges, fund transfer fees, swift charges, account maintenance fees and more. Commissions are risk associated proportional to the amount of the transactions and fees are only transaction dependent, not on the risk involved (McNaughton \& Barltrop, 1992).

\section{METHODOLOGY}

In this study, we have used a panel data set. Thus, we choose to use fixed effect or random effect for the study to investigate the relationship between the variables. Use of panel data for such research serves noteworthy advantages over cross-sectional or time-series data analysis (Hsiao, 2003). It has greater degrees of freedom and variability of sample, which finally improves the efficiency highly. The applied models in the study are:

Model for fixed effect:

$$
\begin{aligned}
& \log \text { Roe }_{i t}=\alpha+\beta_{1} \log \text { Npl }_{i t}+\beta_{2} \log \text { Ldratio }_{i t}+ \\
& +\beta_{3} \log \text { Intincome }_{i t}+\beta_{4} \log \text { cofund }_{i t}+ \\
& +\beta_{5} \log \text { niba }_{i t}+\beta_{6} \log \text { Cincome }_{i t}+ \\
& +\beta_{7} \log \text { Comm }+\beta_{8} \log \text { Opt } \exp _{i t}+ \\
& +\beta_{9} \log \text { Povcl }_{i t}+\varepsilon_{i t},
\end{aligned}
$$

$\log \operatorname{Roa}_{i t}=\alpha+\beta_{1} \log N p l_{i t}+\beta_{1} \log$ dratio $_{i t}+$ $+\beta_{3} \log$ Intincome $_{i t}+\beta_{4} \log$ cofund $_{i t}+$ $+\beta_{5} \log n i b a_{i t}+\beta_{6} \log$ Cincome $_{i t}+$ $+\beta_{7} \log$ Comm $+\beta_{8} \log$ Opt $\exp _{i t}+$

$+\beta_{9} \log$ Povcl $_{i t}+\varepsilon_{i t}$.

Model for random effect:

$$
\begin{aligned}
& \log \text { Roe }_{i t}=\alpha+\beta_{1} \log \text { Npl }_{i t}+\beta_{2} \log \text { Ldratio }_{i t}+ \\
& +\beta_{3} \log \text { Intincome }_{i t}+\beta_{4} \log \text { cofund }_{i t}+ \\
& +\beta_{5} \log \text { niba }_{i t}+\beta_{6} \log \text { Cincome }_{i t}+ \\
& +\beta_{7} \log \text { Comm }+\beta_{8} \log \text { Opt } \exp _{i t}+ \\
& +\beta_{9} \log \text { Povcl }_{i t}+\mu_{i t}+\varepsilon_{i t},
\end{aligned}
$$

$$
\begin{aligned}
& \log \text { Roa }_{i t}=\alpha+\beta_{1} \log \text { Npl }_{i t}+\beta_{2} \log \text { Ldratio }_{i t}+ \\
& +\beta_{3} \log \text { Intincome }_{i t}+\beta_{4} \log \text { cofund }_{i t}+ \\
& +\beta_{5} \log \text { niba } \\
& i t \\
& +\beta_{6} \log \text { CincomeR }_{i t}+ \\
& +\beta_{7} \log \text { Comm }+\beta_{8} \log \text { Opt } \exp _{i t}+ \\
& +\beta_{9} \log \text { Povcl }_{i t}+\mu_{i t}+\varepsilon_{i t} .
\end{aligned}
$$

Many empirical studies have used fixed effect and random effect estimation techniques. The methodology is well established and published in a large number of research studies. Therefore, we refrain from further discussion on the methods of fixed effect and random effect. For details methodological analysis, please see: Allison (2009), Gujarati (2014), Laird and Ware (1982), Liang and Zeger (1986). 


\section{ANALYSIS AND DISCUSSION}

Table 1. Summary statistics

\begin{tabular}{|c|c|c|c|c|c|}
\hline Variable & Obs & Mean & $\begin{array}{l}\text { Std. } \\
\text { Dev. }\end{array}$ & Min & Max \\
\hline ROA & 175 & .014 & .007 & 0 & .04 \\
\hline ROE & 140 & .32 & 1.61 & .03 & 19.19 \\
\hline $\begin{array}{l}\text { Interest } \\
\text { income }\end{array}$ & 175 & 9.02 & 5.58 & 1.46 & 2.30 \\
\hline Commission & 175 & 1.32 & 8.15 & 1.39 & 5.14 \\
\hline $\begin{array}{l}\text { Operating } \\
\text { exp }\end{array}$ & 175 & 2.71 & 2.02 & 0.737 & 1.04 \\
\hline NPL & 175 & .039 & .019 & 0 & .14 \\
\hline Cost of fund & 175 & .090 & .018 & .05 & .14 \\
\hline $\begin{array}{l}\text { Cost to } \\
\text { income ratio }\end{array}$ & 112 & .46 & .135 & .26 & .82 \\
\hline Ld ratio & 175 & .84 & .074 & .66 & 1.09 \\
\hline
\end{tabular}

To determine which of the models is appropriate for the study, we run the Hausman Test developed by Hausman (1978) (Table 2) that suggests that random effect regression is appropriate for both the models.

Table 2. Hausman test to find the appropriate model

\begin{tabular}{l|c}
\hline \multicolumn{1}{c|}{ Hausman test } & Prob>chi2 \\
\hline For model 1 (ROA) & 0.1989 \\
\hline For model 2 (ROE) & 0.0519 \\
\hline
\end{tabular}

Note: Ho: difference in coefficients is not systematic.

The Hausman test has finally shown that for both dependent variable ROA and ROE the random effect model is appropriate. We now further proceeds to estimate the models. The result of the estimation is presented in Tables 3 and 4.

Table 3. Model 3 (Determinants of return on asset, robust estimation)

\begin{tabular}{|c|c|c|c|c|}
\hline Dependent variables & Coef. & Robust std. err. & $\mathbf{z}$ & $P>|z|$ \\
\hline log_npl & -.2906928 & .087322 & -3.33 & $0.001^{* * *}$ \\
\hline log_Idratio & .5460527 & .3851468 & 1.42 & 0.156 \\
\hline log_interestincome & -.1784071 & .1286135 & -1.39 & 0.165 \\
\hline log_costoffund & .0526888 & .048989 & 1.08 & 0.282 \\
\hline log_noninterestbearingasset & .0675524 & .0497277 & 1.36 & 0.174 \\
\hline log_costtoincomeratio & -.6030709 & .171317 & -3.52 & $0.000^{* * *}$ \\
\hline log_commission & .3144528 & .136196 & 2.31 & $0.021^{* *}$ \\
\hline log_operatingexp & -.1909235 & .0754647 & -2.53 & $0.011^{* *}$ \\
\hline Cons & -5.520707 & 1.513708 & -3.65 & 0.000 \\
\hline
\end{tabular}

Note: ${ }^{* * *}$ indicates significance at 1 percent, ${ }^{* *}$ at 5 percent and ${ }^{\star}$ at 10 percent level.

Table 4. Model 4 (determinants of return on equity, robust estimation)

\begin{tabular}{|c|c|c|c|c|}
\hline Dependent variables & Coef. & Robust std. err. & $\mathbf{z}$ & $P>|z|$ \\
\hline log_npl & -.3673757 & .1501876 & -2.45 & $0.014^{* *}$ \\
\hline log_Idratio & .3306842 & .9399965 & 0.35 & 0.725 \\
\hline log_costoffund & .1291257 & .0820427 & 1.57 & 0.116 \\
\hline log_noninterestbearingasset & -.0955065 & .1450555 & -0.66 & 0.510 \\
\hline log_costtoincomeratio & .0044549 & .2481902 & 0.02 & 0.986 \\
\hline log_commission & .4267675 & .2256536 & 1.89 & $0.059 *$ \\
\hline log_operatingexp & -.2985147 & .0948495 & -3.15 & $0.002^{* * *}$ \\
\hline _cons & -2.935774 & 2.100382 & -1.40 & 0.162 \\
\hline
\end{tabular}

Note: ${ }^{\star *}$ indicates significance at 1 percent, ${ }^{\star \star}$ at 5 percent and ${ }^{\star}$ at 10 percent level. 
For model 3, most of the explanatory variables show anticipated sign. Among them, nonperforming loan and cost to income ratio are significant at $1 \%$ level. On the other hand, commission and operating expenses are significant at $5 \%$ level. The results of the study indicate that a $1 \%$ increase in the non-performing loan of the selected banks reduces the growth in return on assets by $0.29 \%$. Nonperforming loans amount of the bank have to provision or deducted from profit as Bangladesh Bank regulation based on classification status. Thus non-performing loan reduces profit by a significant amount. Similarly, a $1 \%$ growth in the cost to income ratio and $1 \%$ growth in the operating expenses reduce the growth in return on assets by $0.60 \%$ and $0.19 \%$, respectively. On the other hand, growth in commission earning has positive and significant relationship with growth in return on assets. According to the result, a $1 \%$ growth in commission earning increases the growth in return on assets by $0.31 \%$. although loan and deposit ratio, cost of acquiring fund and non-interest bearing assets all have positive relationship with the growth of return of assets, their results are statically insignificant.

From the results, we can see that for model 4 NPL as has significant negative relationship (at $5 \%$ level) with return on equity. The random effect estimation (robust) results show that a $1 \%$ growth in the NPL reduces the growth in return on equity by $0.37 \%$. In addition, the results of commission and operating expenses also show significant results at $5 \%$ and $1 \%$, respectively, with expected signs. When the earnings from commission goes up by $1 \%$ the return on equity increases by $0.43 \%$. However, a $1 \%$ growth in the operating expenses reduces the growth in return on equity by $0.30 \%$. Interestingly, although loan to deposit ratio, cost of fund, cost to income ratio shows expected signs that their results are not significant. Similar results were also found by other literatures such as Demirguc-Kunt (1989) and Barr and Siems (1994).

\section{OTHER DIAGNOSTIC TESTS}

In this study, we have conducted the Hausman test in Table 2 to decide between using the random fixed effect and random effect model. The results of the test presented in Table 2 shows that both ROA and ROE random effect model are appropriate. The random effect model considers the constant for each section as random parameters. That means it assumes that each bank in this study differs in its error term as the sample contains limited observations of cross-sectional unit here the random effect model is more appropriate. We have also conducted Wooldridge test for autocorrelation. The results in Table 5 suggest that no significant serial correlation exist in any of the models. Moreover, a modified Wald test for model 1 and 2 shows that both the model contains heteroscedasticity thus we use a robust standard error to counter the problem of heteroscedasticity (see Table 6). We consider our data as micro panel as $\mathrm{N}$ is greater than $>\mathrm{T}$. That means here we have 10 years data for 15 banks thus we assume no cross-section dependence. That means the residuals across the entities are not correlated.

Table 5. Wooldridge test for autocorrelation

\begin{tabular}{l|c}
\hline \multicolumn{1}{c|}{ Wooldridge test for autocorrelation } & Prob $>$ F \\
\hline For model 1 (ROA) & 0.0530 \\
\hline For model 2 (ROE) & 0.2132 \\
\hline
\end{tabular}

Note: Ho: no first-order autocorrelation.

Table 6. Modified Wald test for group wise heteroscedasticity

\begin{tabular}{l|c}
\hline Modified Wald test for group wise heteroscedasticity & Prob>chi2 \\
\hline For model 1 (ROA) & 0.000 \\
\hline For model 2 (ROE) & 0.000 \\
\hline
\end{tabular}

Note: Ho: homoscedasticity or constant variance. 
Table 7. Correlation matrix model (ROA)

\begin{tabular}{|c|c|c|c|c|c|c|c|c|c|}
\hline & log_roa & log_npl & $\log I d \sim \sim 0$ & log_in $\sim e$ & $\log _{-}$co d & $\log \_n o \sim t$ & $\log$ co $\sim 0$ & $\log \_c o \sim n$ & $\log \_o p \sim p$ \\
\hline log_roa & 1.0000 & & & & & & & & \\
\hline log_npl & -0.352 & 1.0000 & & & & & & & \\
\hline log_Idratio & 0.4161 & -0.174 & 1.0000 & & & & & & \\
\hline log_intere e & -0.058 & 0.223 & 0.0658 & 1.0000 & & & & & \\
\hline log_costof $\sim d$ & 0.0983 & 0.031 & -0.0257 & 0.0194 & 1.0000 & & & & \\
\hline log_nonint $\sim t$ & -0.069 & 0.2030 & -0.1135 & 0.8059 & 0.0744 & 1.0000 & & & \\
\hline log_costto o & -0.550 & 0.050 & -0.3329 & -0.1698 & -0.0816 & -0.1295 & 1.0000 & & \\
\hline log_commis n & 0.1007 & 0.149 & 0.2752 & 0.6380 & 0.1750 & 0.4767 & -0.2747 & 1.0000 & \\
\hline log_operat p p & -0.070 & 0.129 & 0.1074 & 0.5320 & 0.1579 & 0.4451 & -0.1088 & 0.9185 & 1.0000 \\
\hline
\end{tabular}

Table 8. Correlation matrix model (ROE)

\begin{tabular}{|c|c|c|c|c|c|c|c|c|c|}
\hline & log_roe & log_npl & $\log I d \sim 0$ & $\log \_$in $\sim e$ & $\log \_c o \sim d$ & $\log \_n o \sim t$ & $\log \_c 0 \sim 0$ & $\log \_$co $\sim n$ & $\log \_o p \sim p$ \\
\hline log_roe & 1.0000 & & & & & & & & \\
\hline log_npl & -0.261 & 1.0000 & & & & & & & \\
\hline log_Idratio & 0.1941 & -0.179 & 1.0000 & & & & & & \\
\hline log_intere e & -0.259 & 0.2342 & 0.0576 & 1.0000 & & & & & \\
\hline $\log \_$costof $\sim d$ & 0.0717 & 0.0238 & -0.0250 & 0.0138 & 1.0000 & & & & \\
\hline log_nonint $\sim \mathrm{t}$ & -0.168 & 0.1954 & -0.0513 & 0.6465 & 0.0648 & 1.0000 & & & \\
\hline log_costto o & -0.108 & 0.0637 & -0.3508 & -0.1544 & -0.0851 & -0.1550 & 1.0000 & & \\
\hline log_commis n & -0.044 & 0.1584 & 0.2845 & 0.6374 & 0.1700 & 0.4211 & -0.275 & 1.0000 & \\
\hline log_operat p & -0.138 & 0.1391 & 0.1024 & 0.5362 & 0.1542 & 0.3669 & -0.1021 & 0.9152 & 1.0000 \\
\hline
\end{tabular}

\section{CONCLUSION}

From the empirical results, it is evident that NPLs and operating expenses play a pivotal role in determining the profitability of the private commercial banks of Bangladesh. The analysis shows that high NPLs are the main threat to bank's profitability. This outcome is predictable because previous studies also indicated that NPLs reduce the expected returns of the commercial banks. Bank's high NPLs not only affect its profitability, but also affect the country economy. The study also finds that over the last 10 years in amount commercial banks NPLs are increasing, although average percentages of NPLs are decreasing. The analysis also shows that high operating expenses also reduces the profitability of the banks. It is evident from the previous literature that smaller banks often find it difficult to cut operating expenses significantly. Again, commercial banks should focus on evaluating the bank efficiency ratio in order to maintain the operating expenses at an acceptable margin. Table 3 validates the argument as the cost to income ratio shows a significant negative relationship with return on asset for the private commercial banks of Bangladesh.

\section{REFERENCES}

1. Allison, P. D. (2009). Fixed effects regression models, 160 . SAGE publications. Retrieved from https://us.sagepub.com/en-us/nam/ fixed-effects-regression-models/ book226025
2. Almazari, A. A. (2014). Impact of internal factors on bank profitability: Comparative study between Saudi Arabia and Jordan. Journal of Applied Finance and Banking, 4(1), 125. Retrieved from http://www.sci-
enpress.com/Upload/JAFB/Vol\%20 4_1_7.pdf

3. Ani, W. U., Ugwunta, D. O., Ezeudu, I. J., \& Ugwuanyi, G. O. (2012). An empirical assessment of the determinants of bank profitability in 
Nigeria: Bank characteristics panel evidence. Journal of Accounting and Taxation, 4(3), 38. Retrieved from http://academicjournals.org/article/ article1379422336_Ani\%20et\%20 al.pdf

4. Athanasoglou, P. Delis. M., \& Staikouras, C. (2006). Determinants of bank profitability in the Southern Eastern European region (MPRA Paper No. 10274). Retrieved from https://mpra.ub.uni-muenchen. de/10274/

5. Bangladesh Bank (2015). Banking Performance Indicators Appendix IV. Retrieved from https://www. bb.org.bd/pub/annual/anreport/ ar1415/index1415.php

6. Barr, R. S., \& Siems, T. F. (1994). Predicting bank failure using DEA to quantify management quality (No. 94-1). Federal Reserve Bank of Dallas.

7. Barseghyan, L. (2004). Nonperforming Loans, Prospective Bailouts, and Japan's Slowdown. Cornell University, New York, NY, USA.

8. Bhattacharya, U., \& Ravikumar, B. (2001). Capital markets and the evolution of family businesses. The Journal of Business, 74(2), 187-219.

9. Carter, D. A., \& McNulty, J. E. (2005). Deregulation, technological change, and the business-lending performance of large and small banks. Journal of Banking \& Finance, 29(5), 1113-1130.

10. Carter, D. A., McNulty, J. E., \& Verbrugge, J. A. (2004). Do small banks have an advantage in lending? An examination of risk-adjusted yields on business loans at large and small banks. Journal of Financial Services Research, 25(2-3), 233-252.

11. Chantapong, S. (2005). Comparative study of domestic and foreign bank performance in Thailand: The regression analysis. Economic Change and Restructuring, 38(1), 63-83.

12. De Lis, S. F., Pagés, J. M., \& Saurina, J. (2001). Credit growth, problem loans and credit risk provisioning in Spain. BIS Papers, 1, 331-353.

13. Demirgüç-Kunt, A. (1989). Depositinstitution failures: A review of empirical literature. Economic Review, 25(4), 2-19.
14. Dietrich, A., \& Wanzenried, G. (2011). Determinants of bank profitability before and during the crisis: Evidence from Switzerland. Journal of International Financial Markets, Institutions and Money, 21(3), 307-327. Retrieved from http://econpapers.repec.org/article/ eeeintfin/v_3a21_3ay_3a2011_3ai_ 3a3_3ap_3a307-327.htm

15. Duraj, B., \& Moci, E. (2015). Factors influencing the bank profitability - Empirical evidence from Albania. Asian Economic and Financial Review, 5(3), 483. Retrieved from http://www.aessweb.com/pdf-files/ aefr-2015-5(3)-483-494.pdf

16. Goddard, J., Molyneux, P., \& Wilson, J. O. (2004). The profitability of European banks: A cross-sectional and dynamic panel analysis. The Manchester School, 72(3), 363-381.

17. Gujarati, D. (2014). Econometrics by example. Palgrave Macmillan. Retrieved from https://he.palgrave. com/page/detail/Econometrics-byExample/?K=9781137375018

18. Hausman, J. A. (1978). Specification tests in econometrics. Econometrica: Journal of the Econometric Society, 46(6), 12511271.

19. Hsiao, C. (2003). Analysis of panel data. Econometric Society Monographs, 11. Cambridge University Press, New York.

20. International Monetary Fund (2009). Global Financial Stability Report, April, Washington, DC: IMF.

21. Kaya, A. (2002). Aesthetics of diaspora: contemporary minstrels in Turkish Berlin. Journal of Ethnic and Migration Studies, 28(1), 43-62.

22. Laird, N. M., \& Ware, J. H. (1982). Random-effects models for longitudinal data. Biometrics, 963-974.

23. Liang, K. Y., \& Zeger, S. L. (1986). Longitudinal data analysis using generalized linear models. Biometrika, 73(1), 13-22.

24. McNaughton, D., \& Barltrop, C. (1992). Banking Institutions in Developing Markets: Building strong management and responding to change, 1. World Bank Publications.
25. Oral, M., \& Yolalan, R. (1990). An empirical study on measuring operating efficiency and profitability of bank branches. European Journal of Operational Research, 46(3), 282-294.

26. Pasiouras, F., \& Kosmidou, K. (2007). Factors influencing the profitability of domestic and foreign commercial banks in the European Union. Research in International Business and Finance, 21(2), 222237.

27. Rajan, R., \& Dhal, S. C. (2003). Non-performing loans and terms of credit of public sector banks in India: An empirical assessment. Occasional Papers, 24(3), 81-121.

28. Scardovi, C. (2015). Holistic Active Management of Non-Performing Loans. Springer Switzerland.

29. Smith, R., Staikouras, C., \& Wood, G. (2003). Non-interest income and total income stability. Cass Business School Research Paper (Bank of England Working Paper No. 198). Retrieved from https://papers.ssrn. $\mathrm{com} / \mathrm{sol} 3 /$ papers.cfm?abstract_ id $=530687$

30. Staikouras, C. K., \& Wood, G. E. (2011). The determinants of European bank profitability. International Business \& Economics Research Journal (IBER), 3(6).

31. Sufian, F. (2011). Profitability of the Korean banking sector: Panel evidence on bank-specific and macroeconomic determinants. Journal of Economics and Management, 7(1), 43-72.

32. Sufian, F., \& Habibullah, M. S. (2009). Bank specific and macroeconomic determinants of bank profitability: Empirical evidence from the China banking sector. Frontiers of Economics in China, 4(2), 274-291.

33. Swamy, V. (2012). Determinants of bank asset quality and profitabilityAn empirical assessment (MPRA Paper No. 47513). Retrieved from https://mpra.ub.uni-muenchen. de/47513/

34. Vittas, D. (1991). Measuring commercial bank efficiency: Use and misuse of bank operating ratios, 806. World Bank Publications. 